\title{
North American Labor History Conference
}

\author{
Mary Wingerd, Michael McQuarrie, and George Waldrep \\ Duke University
}

Despite reports to the contrary, labor history is very much alive and well, as demonstrated by the sixteenth annual North American Labor History Conference. Organized under the able direction of Elizabeth Faue, panelists explored promising avenues of scholarship within an international and comparative framework. The innovative tenor of the research revealed that labor historians are engaging in broad theoretical dialogues as well as expanding the parameters of study beyond the limits of national boundaries.

Presentations included work on Africa, Britain, France, Italy, Sweden, Canada, and Australia, and addressed issues of migration and immigration in the United States. Three primary themes emerged from the conference: the utility of a nationally comparative model; the existence of a transnational working class; and the importance of questions of identity and ideology, particularly as reconfigured by the "linguistic turn" of postmodern scholarship.

In the first plenary session ("Is Class Still a Subject?") Geoff Eley provocatively addressed the tension between discourse and class analysis. Drawing on work in progress with collaborator Keith Nield, Eley argued that class is only one strand in the multiplicity of identities that govern human behavior, positioning class identity as "always in the making," unstable, shifting, and unfixed. Though he emphasized that discursive understandings are grounded in a materialist base, Eley questioned the primacy of materialist causality. He suggested that, if social history, focusing on class as a demonstrable socioeconomic fact, has failed to provide a satisfactory explanation for political choices, then perhaps a focus on the discourse of class as created in the political arena would provide a better basis for continued investigation and mobilization. Needless to say, the implications of his analysis elicited a lively response from the audience.

A number of the participants addressed the complexities of identity. In analyzing Italian immigrant workers, Franco Ramella found that a persistent focus on class obscures the importance of ethnic identity-an identity that, in his view, was largely imposed by the dominant class as a means of exclusion. In a similar vein, Kevin Kenny argued that the mythic identity of the Molly Maguires in America was manufactured almost wholly by hostile witnesses, reflecting more about contemporary nativism and antiCatholicism than about actual Irish-American labor activism. Mary McGuire examined the ideology of American and German postal workers, concluding that the constructed identity of "public servant" and its concurrent conception of duty to the state legitimized but also limited the scope of 
potential protest. In the case of silkweavers in early nineteenth-century Britain, Marc Steinberg found that ideologies growing out of class conflict were central to the construction of citizens' political identity. Andrew Neather illustrated the connections between American workers' conception of themselves as citizens and their understandings of the market in the late nineteenth century. In a case study of work and politics in Ashton-underLyne, Robert Hall focused on the interaction between gender and class identity, concluding that the emergence and decline of Chartism was influenced more by perceived threats to the working-class family than by the desire to expand democratic practices.

National comparisons also provided a fruitful basis for several sessions, including panels based on the work in progress of the AustralianCanadian Labour History Project. A particularly effective national comparison explored the links between racial tension and class conflict in postWorld War I Britain, France, and the United States. Carlton Wilson argued that the Liverpool riots of 1919 were directly attributable to postwar economic conditions that exacerbated latent racial tensions. Tyler Stovall also found job competition to be a major factor in producing racial violence in France, but with a different twist. French men, convinced that colonial workers were being imported to free them for military service, conflated antiwar and anticolonial sentiments into a racist reaction. In his study of 1919 Chicago, Dominic Pacyga reinterpreted the infamous race riots as primarily an attack by the emerging Irish middle class against black workers, rather than as a primarily intra-working-class battle.

The often-neglected role of women in labor migration was addressed in a comparative context in the session "Women and Italian Labor Migration." Panelists Carina Frid Silberstein, Diane Vecchio, Ros Pesman, Ellie Vasta, and Maddalena Tirabassi explored the experiences of Italian women in Argentina, the United States, and Australia, as well as women's role in facilitating male labor migration. Panel chair Donna Gabaccia noted that these papers, taken together, provided a look at the global economy from the bottom up and raised the issue of women's role in an international division of labor, both at home and abroad. The questions posed by these scholars are a reminder that a great deal of work remains to be done to incorporate gender fully into labor history, rather than confining it to a separate subfield of working-class women's history.

The permeability of national boundaries was apparent in the many papers that examined transnationalism and the migration of radical ideologies. This theme was given dramatic voice by Peter Linebaugh and Marcus Rediker, who called for an exploration of the Atlantic mercantile economy and its multiracial, multiethnic, and international proletariat, which existed long before the onset of industrial capitalism. Jamie Bronstein's paper on working-class agrarianism illustrated the very tangible transatlantic links between British and American agrarian movements. Michael Miller Topp and Fraser Ottanelli presented papers that explored fascism as the 
pivotal force that transformed Italian-American labor militancy from a transnational to a nationalistic focus. David Brundage examined the tension between Irish nationalism and Irish-American working-class activism. In comments, Dirk Hoerder cautioned that internationalist consciousness for workers seems to fragment immediately with the outbreak of war and that ideological transnationalism among radical leaders may be a wholly separate phenomenon.

The conference also made important connections between labor historians, the portrayal of public history, and activism. The second plenary session was devoted to current organizational concerns and included a forceful talk by Brad Markell of the UAW on transnational labor solidarity. At an earlier panel, Beverly Butler, in a creative multimedia presentation, explored the possibilities and limitations of labor history as public history.

The broad scope of research presented revealed many auspicious new directions for labor history, only a few of which can be reported here. Rather than moving toward synthesis, we appear to be in a period of creative ferment that suggests a range of intellectual and political challenges rather than pessimism for the future of the field.

\title{
Theories, Methods, and Concepts in Social and Cultural History: Report on the Social History Society Conference, York
}

\author{
Ann McCrum \\ University of Edinburgh
}

The January 1995 Social History Society conference opened with a plenary lecture by Carolyn Steedman (University of Warwick) entitled "Linguistic Encounters of the Fourth Kind." The major focus of the paper was the adoption of the term "language" to mean "discourse" in the Foucauldian sense and therefore the neglect of language in the linguistic sense. The vehicle for the analysis was a case study of a memoir written in 1881 by a retired policeman in his sixties. In the middle of the memoir there is a move from simple one-to-one articulation to an analysis of qualitative material using such concepts as capital and production. As the writing departs from a routine personal description and becomes a debate with the author himself, Steedman suggested that the transition is the result of a significant encounter with "culture," for which the act of writing is the catalyst. Thus the relative perspective of the memoir writer's vision is in the narrative itself, which carries its own message in the form or medium of the language used. 